\title{
Protein Kinase
}

National Cancer Institute

\section{Source}

National Cancer Institute. Protein Kinase. NCI Thesaurus. Code C17018.

A class of phosphotransferase proteins that posttranslationally modify protein substrates through the addition of phosphate groups. 